\title{
Daily Integrated Generation Scheduling for Thermal, Pumped-Storage Hydro and Cascaded Hydro Units and Purchasing Power Considering Network Constraints
}

\author{
Toshiyuki Sawa Senior Member (Hitachi, Ltd., toshiyuki.sawa.zu@hitachi.com) \\ Yasuo Sato Member (Hitachi, Ltd.) \\ Mitsuo Tsurugai Member (Hitachi, Ltd.) \\ Tsukasa Onishi Member (Hitachi, Ltd.)
}

Keywords: unit commitment, quadratic programming, interior point method, hydrothermal, minimum up- and down-times, network constraints

Deregulation of electric power industries has been spreading extensively. In Japan ten vertically integrated utilities operate and manage the power system for their region. To be competitive under these conditions, utilities must reduce operating costs and manage transmission congestion in their region. Therefore a solution that satisfies all constraints including system security and transmission line flow constraints is required for the utilities managing power systems. The generation scheduling problem is a complex and largescale mixed integer programming problem.

The objective of generation scheduling problem is to minimize total operation costs, that is, the sum of generation and unit start-up costs over the scheduling horizon. We have developed an innovative power generation scheduling method using quadratic programming (QP). The advantage of using our method is that it simultaneously solves unit commitment and economic load dispatch. We relax the binary variables of the unit state into continuous variables to apply QP to this problem. We also add the penalty term to converge the value of those variables to 0 or 1 to the objective function; the sum of fuel costs and start-up costs. This penalty term depends on per-unit fuel cost. The possibility of its variable converging to zero increases as the cost increases. Figure 1 shows the procedure for scheduling generation using the proposed method. To speed convergence of variables $u_{i t}$, maximum iteration number $d_{\max }$ is set at four, and the penalty-weighting factor $\mathrm{w}^{\mathrm{d}}$ is zero or $10^{\mathrm{d}}$ when iteration number $d$ is zero or above, respectively.

The developed method was applied to a test system of daily

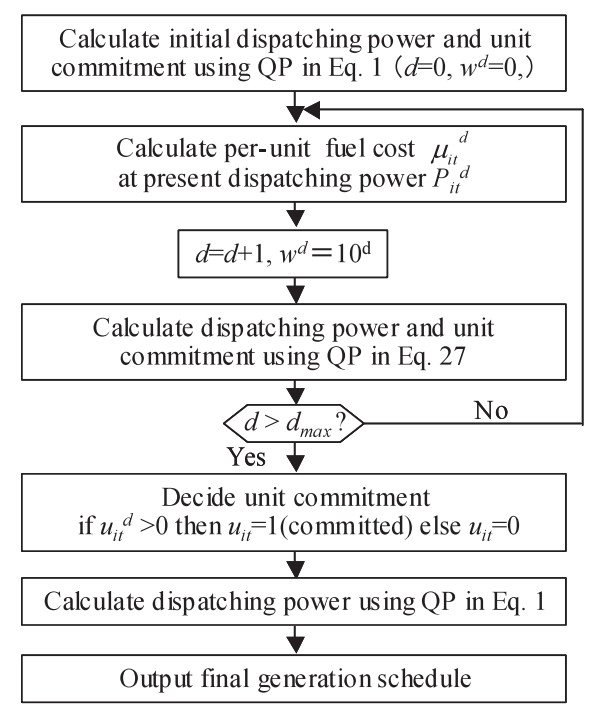

Fig. 1. Procedure for scheduling daily generation

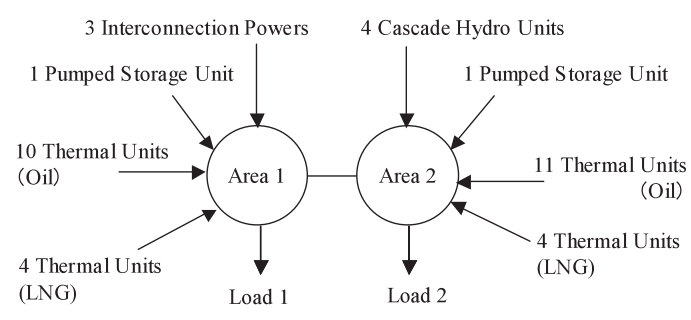

Fig. 2. Test system

Table 1. Generation costs

(Normalized by generation costs of conventional method)

\begin{tabular}{|c|c|c|c|}
\hline Method & Conventional & Proposed & Lower Bound \\
\hline Costs & 1.00000 & 0.99916 & 0.99335 \\
\hline
\end{tabular}

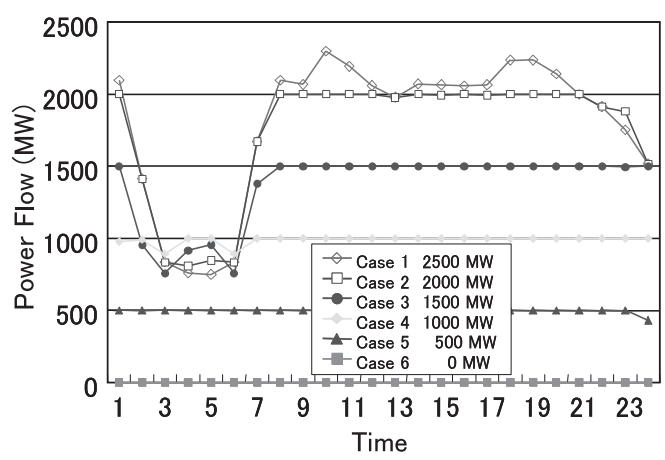

Fig. 3. Power flow in each power flow limit case

generation scheduling that consisted of 29 thermal units, two pumped-storage units, four cascaded-hydro units, and one transmission (Fig. 2).

Table 1 shows generation costs. We use the priority list method as the conventional method. The schedules by the conventional and proposed methods satisfy all constraints and are feasible. The lower bound costs in the third column are the first iteration costs calculated by the proposed method. This schedule is not feasible. Total generation costs are reduced by $0.084 \%$.

The proposed method considering network constraints provided a feasible solution for all six cases (Fig. 3). As the power flow limit decreases, the difference increases. The differences between the solutions obtained with the proposed method and the optimal solutions amount to only $0.5 \%$ to $1.0 \%$.

The schedule satisfied all constraints, i.e., load-power balance, operation reserve, power flow, minimum up/down-times, and fuel consumption. This result shows that the developed method is effective. 


\title{
潮流制約を考慮した火力，揚水，水力及び融通の 統合翌日運用計画作成
}

\author{
上級会員 澤 敏之* 正 員 佐藤 康生* \\ 正 員 鶴貝 満男 ${ }^{* *}$ 正 員 大西 司**
}

\section{Daily Integrated Generation Scheduling for Thermal, Pumped-Storage Hydro and Cascaded Hydro Units and Purchasing Power Considering Network Constraints}

Toshiyuki Sawa*, Senior Member, Yasuo Sato*, Member, Mitsuo Tsurugai**, Member, Tsukasa Onishi**, Member

We have developed an innovative power generation scheduling method using quadratic programming (QP). The advantage of using our method is that it simultaneously solves unit commitment and economic load dispatch. We relax the binary variables of the unit state into continuous variables to apply QP to this problem. We also add the penalty term to converge the value of those variables to 0 or 1 to the objective function; the sum of fuel costs and start-up costs. This penalty term depends on per-unit fuel cost. The possibility of its variable converging to zero increases as the cost increases. This method was applied to a test system of daily generation scheduling that consisted of 29 thermal units, two pumped-storage units, four cascaded-hydro units, and one transmission. The schedule satisfied all constraints, i.e., load-power balance, operation reserve, power flow, minimum up/down-times, and fuel consumption. This result shows that the developed method is effective.

キーワード : 起動停止計画, 二次計画法, 内点法, 火力水力, 最小連続運転・停止時間, 潮流制約

Keywords: unit commitment, quadratic programming, interior point method, hydrothermal, minimum up- and down-times, network constraints

\section{1. まえがき}

規制緩和，電力自由化は欧米で先駆けて開始され，卸電 力取引所や系統運用者が設置されている。日本においても, 経済産業大臣の諮問機関である総合資源エネルギー調査会 の 2003 年 2 月に電気事業分科会より「今後の望ましい電 気事業制度の骨格について」(1) が報告され，2005 年 4 月よ り卸電力取引所での電力取引が開始された。

国内の電力自由化では諸外国との電気料金の格差を是正す ることが目的のひとつであった。2000 年 3 月の $2000 \mathrm{~kW}$, $20 \mathrm{kV}$ 以上の需要家 (電力量の $26 \%$ ) を対象とした小売部分 自由化に始まって, 2004 年 4 月の $500 \mathrm{~kW}$ (電力量の 40\%), 2005 年の $50 \mathrm{~kW}$ (電力量の $63 \%$ ) と小売自由化の範囲が 拡大している。一般電気事業者と新規参入者 PPS はお互い

\footnotetext{
* (株) 日立製作所 日立研究所

厂319-1292 日立市大みか町 7-1-1

Hitachi Research Laboratory, Hitachi Ltd.

1-1, Omika-cho 7-chome, Hitachi 319-1292

**（株）日立製作所情報制御システム事業部

干 319-1293 日立市大みか町 5-1-1

Information \& Control Systems Div., Hitachi Ltd.

1-1, Omika-cho 5-chome, Hitachi 319-1293
}

に小売部門で競争にさらされている。一般電気事業者の支 出に占める発電コストの割合は $30 \%$ 程度である。一般電気 事業者がより一層競争力を高めるためには, 現状の高い供 給信頼度を維持しながら発電コストを低減することが重要 課題のひとつである。この発電コストの削減に直結するの が発電所運用計画である。

発電所運用計画問題は発電機の起動停止問題と負荷配分 問題からなり, 前者は組合せ問題であり, 後者は非線形計画 問題となっている。すなわち, 非線形混合整数計画問題と なっており, 一般電気事業者の発電設備を対象とした大規 模な問題を最適化するのは事実上不可能である。このため, 近似的な数々の手法が提案されている(2)。運用者にとって 火力発電所の起動停止計画を作成する最も基本的な手法は 優先順位法 ${ }^{(3) \sim(6)}$ である。この手法は予備力を満たすように 定格出力での発電単価が安い発電機から起動していき, 作 成された計画を運用者が理解しやすく, 簡単な方法である にもかかわらず比較的発電コストを安くできる手法である。 厳密な最適解を求めることができる動的計画法 ${ }^{(7) \sim(10)}$ や分 枝限定法 ${ }^{(11) \sim(13)}$ による手法も開発されているが，計算時間 が膨大になることから実規模問題を解くことはできていな い。このため, 計画作成の一部に動的計画法を使う方法が 
いくつかある。代表的な方法にラグランジュ緩和法 ${ }^{(14) \sim(19)}$ がある。この方法は大規模問題が扱えることが特徵で, 発 電機毎に独立に動的計画法を使って起動停止計画を作成す る処理と需給バランスを満たすように時間断面毎のラグラ ンジュ乗数の修正処理を交互に繰り返す方法である。但し， 収束性の問題があることが指摘されている。同様に, 動的 計画法を利用する方法として, Unit Decommitment ${ }^{(20)(21)}$ が ある。この方法は，すべての発電機を運転状態から発電機 毎に動的計画法により停止発電機を確定していく方法であ り，一度停止した発電機の計画を修正しないので, 必ず収束 することが保障されており，高速である。但し，燃料消費 制約などの制約を考慮することは難しい。最近は組合せ最 適化問題の近似解法として注目を浴びている遺伝的アルゴ リズムやタブサーチ法を使った方法も提案されている。遺 伝的アルゴリズム ${ }^{(22) \sim(24)}$ の特徵は, 生物の進化を模擬して 集団で最適解を求めることである。但し，単純にコーディ ングした遺伝子とすると探索空間が広くなってしまう問題 がある。また，乱数を使うため，同一問題に対して得られ る解が異なることがあるため, 運用者から見てわかりにく い課題がある。タブサーチ法 ${ }^{25)(26)}$ もヒューリスティクスの 1 つであるが，遺伝的アルゴリズムと比較して，相対的に 高速であり，乱数を使わないので，同一の問題に対して同 じ解が得られる特徵がある。但し，相対的に高速ではある が，対象問題の特徵をうまく取り入れて適切な空間を探索 するようにすることが重要である。電力自由化に対応して セキュリティを考慮した方法 ${ }^{(18)(27)}$ が提案されている。

発電所運用計画問題については，上記で挙げたいずれの 方法も, まず発電機の起動停止問題を解いて, 次に負荷配

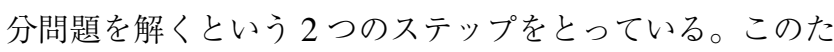
め, 起動停止と負荷配分にかかわる各種の運用制約を同時 に考慮するとともに，起動停止と負荷配分を最適化するこ とが難しいが。そこで, 組合せ最適化問題である火力発電 機の起動停止問題に対して, その起動停止变数を連続值に 緩和することにより，二次計画法を用いて火力，揚水㧍よ び水力の負荷配分計画も同時に解く定式化方法を開発した。 本論文ではこの開発した定式化方法と実規模問題に適用し たシミュレーション結果について述べる。

\section{2. 翌日運用計画問題の定式化}

$\langle\mathbf{2} \cdot \mathbf{1}\rangle$ 従来の運用計画作成の課題 従来の翌日運用 計画作成の手順について説明する。計画作成にあたっては, 最初に需要実績, 気象予報等を元に翌日の総需要予想を行 う。次に, 原子力発電の他に水力発電および融通電力も固 定供給力として, 総需要予想值から差し引いて, 火力揚水 発電による供給力分を決める。最後に, 可変供給力として 扱う火力発電所, 揚水発電所のスケジュールを系統運用制 約, 発電所の運用制約等を考慮して起動停止計画, 負荷配 分計画を作成している。ここで，火力，揚水発電所の計画 を作成するときは, 最初に火力発電所の起動停止計画と負 荷配分計画を作成し，次にこの計画結果を前提として揚水
発電所の計画を作成するという手順が通常とられている。

以上のように，それぞれの供給力種別毎の特性に応じて， 順次計画を確定しながら，各供給力の計画を作成している のが現状である。このため, 供給力全体でみたときには必 ずしも最適化がなされているとは言えない。より最適な計 画を作成するために, 火力, 揚水発電所とともに, 水力, 融 通電力も可変供給力と考え, それらを統合的に捉えて, 同 時に計画を作成することにより, 発電費用の抑制を図る計 画を作成することが必要である。

$\langle\mathbf{2} \cdot \mathbf{2}\rangle$ 一般的な定式化 定式化する上での前提とし て, 翌日の総需要予想值は与えられるものとする。また, 翌 日の供給力の計画では, 原子力等の固定供給力は計画どお りに供給されるものと想定する。つまり, 総需要から原子 力等の固定供給力を引いた差引需要 (以下では差引需要ま たは単に需要と記述) に対して, 可変供給力を割り当てる 計画を作成するものとする。

(1) 目的関数 目的関数は 1 日の需要に対する電力 の供給コストである。供給コストは火力発電機の燃料費, 起動費抢よび融通電力の調達費用からなる。この供給コス トを目的関数とし，(1) 式に示す。

$$
\begin{aligned}
\boldsymbol{F}(\boldsymbol{P}, \boldsymbol{u})= & \sum^{\mathrm{t}} \sum^{\mathrm{i}}\left(a_{i} P_{i t}^{2}+b_{i} P_{i t}+u_{i t} c_{i}\right)+\sum^{\mathrm{i}} \Delta u_{i} S U C_{i} \\
& +\sum^{\mathrm{t}} \sum^{\mathrm{i}} \sum^{\mathrm{j}} v_{i j} k_{i} R_{i \mathrm{jt}} \ldots \ldots \ldots \ldots \ldots \ldots(1)
\end{aligned}
$$

$P_{i t}$ : 火力発電機 $i$ の時刻 $t$ の発電機出力

$a_{i}, b_{i}, c_{i}$ : 火力発電機 $i$ の燃料費特性の係数

$u_{i t}$ : 火力発電機 $i$ の起動停止変数 $(0:$ 停止, 1 : 運転)

$\Delta u_{i}$ : 火力発電機 $i$ の起動の有無 $(0$ : 起動無, 1 : 有 $)$

$S U C_{i}:$ 火力発電機 $i$ の起動費

$v_{i j}$ : 融通電力 $i$ のパターン $j$ の採否 $(0$ : 否, 1 : 採用)

$k_{i}$ : 融通電力 $i$ の調達単価（従量料金のみ可変費と する)

$R_{i j t}$ : 融通電力 $i$ のパターン $j$ の時刻 $t$ の融通量

（2）制約条件翌日運用計画を作成する上で考慮す る制約条件を下記に示す。

(A) 需給バランス

$$
\begin{aligned}
& \sum^{\mathrm{i}} P_{i t}+\sum^{\mathrm{i}} H G_{i t}-\sum^{\mathrm{i}} H P_{i t}+\sum^{\mathrm{i}} W P_{i t} \\
& \quad+\sum^{\mathrm{i}} \sum^{\mathrm{j}} v_{i j} R_{i j t}=D_{t} \ldots \ldots \ldots \ldots \ldots \ldots
\end{aligned}
$$

$H G_{i t}$ : 揚水発電所 $i$ の時刻 $t$ の出力

$H P_{i t}$ : 揚水発電所 $i$ の時刻 $t$ のポンプ負荷

$W P_{i t}$ : 水力発電所 $i$ の時刻 $t$ の出力

$D_{t}:$ 時刻 $t$ の差引需要

（B）予備力 ここでは，火力のみで予備力を確保する 
ものとしている。

$\sum^{\mathrm{i}}\left(P_{i}^{\max }-P_{i t}\right) u_{i t} \geqq R_{t}$

$R_{t}$ : 時刻 $t$ の必要予備力

$P_{i}^{\max }$ : 発電機 $i$ の時刻 $t$ の出力上限

(C) 火力出力上下限

$$
P_{i}^{\min } u_{i t} \leqq P_{i t} \leqq P_{i}^{\max } u_{i t}
$$

$P_{i}^{\min }:$ 発電機 $i$ の時刻 $t$ の出力下限

(D) 火力発電機の最小連続停止時間制約

$$
\text { if }\left(1-u_{i t}\right) u_{i t-1}=1 \text { then } \sum^{\mathrm{t} \sim \mathrm{t}+\mathrm{mdt}-1}\left(1-u_{i t}\right)=m d t_{i}
$$

$m d t_{i}$ : 発電機 $i$ の最小連続停止時間

(E) 火力発電機の最小連続運転時間制約

$$
\text { if } u_{i t}\left(1-u_{i t-1}\right)=1 \text { then } \sum^{\mathrm{t} \sim \mathrm{t}+\mathrm{mut}-1} u_{i t}=m u t_{i}
$$

$m u t_{i}:$ 発電機 $i$ の最小連続運転時間

(F) 潮流制約

$$
\begin{aligned}
& P P_{i t}=D D_{i t}+\sum^{\mathrm{i} \rightarrow \mathrm{j}} P F_{i j t} \\
& P F_{i j t}^{\min } \leqq P F_{i j t} \leqq P F_{i j t}^{\max } \\
& P F_{i j t} \text { : エリア } i \text { からエリア } j \text { の向きの時刻 } t \text { の潮流 } \\
& P P_{i t} \text { : エリア } i \text { の時刻 } t \text { の供給力 } \\
& D D_{i t} \text { : エリア } i \text { の時刻 } t \text { の差引需要 }
\end{aligned}
$$

(G) 燃料消費制約 燃料消費量は LNG タンク基地毎 に LNG 燃料を供給している火力発電機の発電量により換 算している。

$$
L N G_{j}^{\text {min }} \leqq L N G_{j}=\sum^{\mathrm{i} \in \text { タンク } \mathrm{j}} \sum^{\mathrm{t}} P_{i t} \leqq L N G_{j}^{\max }
$$

$i \in \mathrm{LNG}$ タンク $j$ から燃料を供給する発電機

(H) 揚水出力上下限

$$
\begin{aligned}
& H G_{i}^{\min } \leqq H G_{i t} \leqq H G_{i}^{\max } \\
& H P_{i}^{\min } \leqq H P_{i t} \leqq H P_{i}^{\max }
\end{aligned}
$$

（I）揚水池の水位上下限（貯電力量上下限） 水位か ら換算した貯水量を計算し，この貯水量から発電量を換算 した值を用いて，水位上下限制約を設定している。計画の 最終時刻は目標水位を設定すると，このときの水位上下限 值は一致することになる。

$$
\begin{aligned}
& H V_{i t}=H V_{i t-1}-H G_{i t}+\eta_{i} H P_{i t k} \\
& H V_{i t}^{\min } \leqq H V_{i t} \leqq H V_{i t}^{\max } \ldots \ldots \ldots
\end{aligned}
$$

$\eta_{i}$ : 揚水発電所 $i$ の揚水効率
(J) 水力出力上下限

$$
\begin{aligned}
& W P_{i t}^{\min } \leqq W P_{i t} \leqq W P_{i t}^{\max } \ldots \ldots \ldots \ldots \ldots \\
& W P_{i t} \text { : 水力発電機 } i \text { の時刻 } t \text { の出力 }
\end{aligned}
$$

（K） 使用水量上下限電水比はダムの水位等により変 化するが，ここでは，水位の落差の変化による電水比の変 化は少ないとして, 電水比を一定として扱る。

$$
\begin{aligned}
& W Q_{i}^{\text {min }} \leqq W Q_{i t}=W P_{i t} / \kappa_{i} \leqq W Q_{i}^{\max } \\
& W R_{i}^{\text {min }} \leqq W R_{i t} \leqq W R_{i}^{\max } \ldots \ldots \ldots \ldots . .
\end{aligned}
$$

$\kappa_{i}$ : 水力発電機 $i$ の電水比

$W R_{i t}$ : 水力発電機 $i$ の時刻 $t$ の使用水量

（L）ダム，貯水池の水位上下限（貯水量上下限） 水 位の上下限值を貯水量に換算して，この換算した貯水量で 水位上下限制約を設定している。水位上下限值を同一にす ることにより最終時刻の目標水位を設定している。上流ダ ムから放流した水は流下遅れ時間を考慮して下流ダムに到 着するものとする。ここでは, ダム $i$ の上流ダムをダム $i-1$ と表記している。

$$
\begin{aligned}
H L_{i t}= & H L_{i t-1}-W P_{i t}-W Q_{i t}+\left(1-\tau_{i}\right)\left(W P_{i-1 t}+W Q_{i-1 t}\right) \\
& +\tau,\left(W P_{i-1 t-1}+W Q_{i-1 t-1}\right)+W S_{i t} \ldots \ldots \ldots(17) \\
H L_{i t}^{\min } \leqq & H L_{i t} \leqq H L_{i t}^{\max } \ldots \ldots \ldots \ldots \ldots \ldots \ldots \ldots \ldots
\end{aligned}
$$

$H L_{i t}$ : ダム $i$ の時刻 $t$ の貯水量

$W P_{i t}$ : ダム $i$ の上流からの時刻 $t$ の発電放流量 $W Q_{i t}$ : ダム $i$ の上流からの時刻 $t$ の無効放流量 $W S_{i t}$ : ダム $i$ への溪流からの時刻 $t$ の流入量 $\tau_{i}:$ 上流ダム $i-1$ からその下流ダム $i$ までの流下 遅れ時間率（流下遅れ時間／計画の単位時間 $\leqq 1)$

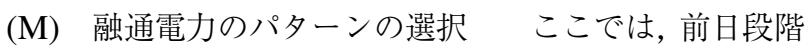
で融通のパターンを指定できる融通電力（二社間融通）を 想定している。指定の銘柄あるいは発電所に対して, 1 つ のパターンを選択する。このとき, 発電しないということ も1つのパターンとしている。

$$
\sum^{\mathrm{j}} v_{i j}=1
$$

$v_{i j}$ : 銘柄 $i$ のパターン $j$ を選択したとき 1 ，そうで ないとき 0

$\langle\mathbf{2 \cdot 3}\rangle$ 二次計画法適用のための定式化 上記で示し たように運用計画問題は火力発電機の起動停止と二次関数 の燃料費を含む混合非線形計画問題である。このため, 実 系統規模の運用計画問題に対して最適解を求めることは事 実上不可能である。そこで, 最適性の悪化を抑えつつ, 計 算量や実行可能性の高い解が二次計画法を適用して得られ るように，ヒューリスティックな制約条件を追加した。す なわち, 発電機の運用制約を考慮する 3 種類の制約緩和お よび制約条件を追加した。 
（1）起動停止変数の緩和 起動停止変数は 0-1 変数 であるが，0から 1 の実数変数に緩和する。

・起動停止変数

$0 \leqq u_{i t} \leqq 1$

（2）融通パターン選択変数の緩和 融通電力につい ても, 融通電力のパターンを選択する 0-1 変数を実数变数 に緩和する。

・融通電力のパターン選択

$$
0 \leqq v_{i j} \leqq 1
$$

（3）起動停止変数の時間変化制約 最小連続運転時 間制約および最小連続停止制約は非線形，離散的であるた め，二次計画法になかに直接取り込むことが難しい。この 制約を取り込まないまま, 火力発電機の起動停止変数を時 間毎に独立に決定すると，起動停止变数の時間的な連続性 を考慮することが出来ない。その結果, 1 時間ごとに起動と 停止を繰り返すような運用計画を作成してしまい，実際の 運用とかけ離れた計画となる可能性がある。このため, 起 動停止変数の時間的な連続性を考慮できるように，下記の 2 つの制約を追加した。

(A) 最小需要時刻 $\mathrm{N}$ から最大需要時刻 $\mathrm{P}$ に向かって, 起 動停止変数は減少しない, 最大需要時刻 $\mathrm{P}$ から最小需要時 刻 $\mathrm{N}$ 向かって, 起動停止変数は増加しないとする時間変化 制約を追加する。起動停止変数ではなく発電機出力の時間 変化を制約として追加することも考えられる。しかし，朝 方の需要増加時に全ての発電機の出力は必ずしも, 増加す るとは限らない。理由は, 需要増加に伴って, 新たな火力 発電機が起動するため, 連続運転していた発電機の出力は 需要が増加するにもかかわらず, 減少することがあるため である。

- 変数変化制約

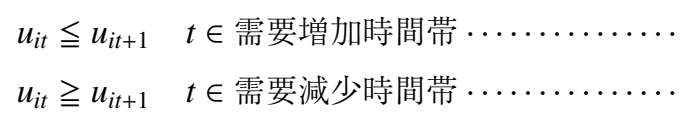

$u_{i t} \geqq u_{i t+1} \quad t \in$ 需要減少時間帯

需要増加時間帯: 時刻 $\mathrm{N}$ から時刻 $\mathrm{P}$

需要減少時間帯：前日時刻 P から時刻 N

時刻 $\mathrm{P}$ から翌日時刻 $\mathrm{N}$

(22)，(23) 式の制約を追加することにより，昼休みに一 次的に需要が減少するのに対応した発電機の停止と起動を 回避できる。この結果，1日に 2 回の起動あるいは停止を 回避して，通常の運用実態にあわせることができる。同様 に, 冬季, 秋季の点灯ピークによる短時間の需要の増減に より，発電機を起動，停止することも回避できる。

(B) 火力発電機の運用制約として, 一旦停止すると連続 して停止しなくてはならないという最小連続停止時間 $m d t$, および一旦運転し始めたら連続して運転しなくてはいけな いという最小連続運転時間 $m u t$ の制約がある。このため, 時刻 N，Pを中心として，それぞれ最小連続停止時間，最
小連続運転時間内の起動停止变数の值は同一とする制約条 件を追加する。ここで, 時刻 N, P を中心としている理由 は, 1 日のなかで時刻 $\mathrm{N}$ の発電機運転台数が最少となり, また時刻 P の運転台数が最多となる運用実態に合わせるた めである。

- 最小連続停止時間制約 $u_{i t}=u_{i t+1}$

$t \in$ 最小需要時間帯

- 最小連続運転時間制約 $u_{i t}=u_{i t+1}$

$t \in$ 最大需要時間帯

最小需要時間帯：時刻 $\mathrm{N}$ を含む連続した $m d t$ 時 点数

最大需要時間帯：時刻 $\mathrm{P}$ を含む連続した $m u t$ 時 点数

以上の制約条件を追加することにより, 火力発電機の起 動費は最大需要時刻の起動停止変数から最小需要時刻の起 動停止変数を引いたものが，(1) 式の $\Delta u_{i}$ となる。つまり, 起動費 $S U C$ は下記で表せることになる。

$$
S U C=\sum^{\mathrm{i}}\left(u_{i n}-u_{i p}\right) S U C_{i}
$$

$n$ : 最小需要時刻, $p$ : 最大需要時刻

\section{3. 処理フロー}

上記の火力発電機の起動停止変数 $u_{i t}$ の実数緩和および制 約条件の追加をしても, 起動停止変数は必ずしも 0 または 1 に収束するとは限らない。つまり, 変数 $u_{i t}$ は 0.8 等の実 数となり, 運用可能解とはならない。この課題を解決する ために, 図 1 に示す運用計画作成フローを採用した。新た

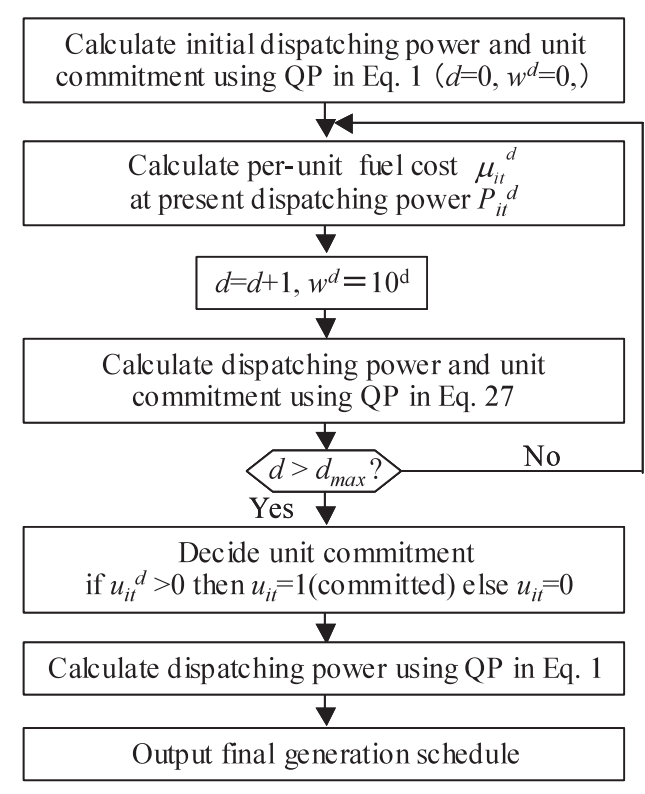

図 1 翌日運用計画作成フロー

Fig. 1. Procedure for scheduling daily generation. 
な目的関数を (1) 式の目的関数に起動停止变数 $u_{i t}$ の線形項 を追加した(27) 式に修正したものとした。(28) 式の発電単 価 $\mu$ が高いものほど運転しにくくなるようにペナルティを 追加するとともに, 更に繰り返し回数 $d$ により重み係数 $w^{d}$ を増大させることにより，起動停止変数 $u_{i t}$ を 0 または 1 に 収束させる。起動停止変数 $u_{i t}$ の線形項のみをぺナルティ として加えることにより, 発電機出力 $P_{i t}$ は (6) 式の出力上 下限制限を受けるが，この出力範囲内において負荷配分の 最適性を維持することができる。この結果，適正に負荷配 分されるので，燃料消費制約への影響を抑制することがで きる。

$$
\begin{array}{r}
\boldsymbol{G}\left(\boldsymbol{P}^{d}, \boldsymbol{u}^{d}\right)=\sum^{\mathrm{t}} \sum_{\mathrm{i}}^{\mathrm{i}}\left(a_{i} P_{i t}^{d 2}+b_{i} P_{i t}^{d}+u_{i t}^{d} c_{i}+w^{d} \mu_{i t}^{d-1} u_{i t}^{d}\right) \\
+\sum^{\mathrm{t}} \Delta u_{i}^{d} S U C_{i}+\sum^{\mathrm{t}} \sum^{\mathrm{i}} \sum^{\mathrm{j}} v_{i j} k_{i} R_{i j t} \\
\mu_{i t}^{d}=a_{i} P_{i t}^{d}+b_{i}+c_{i} / P_{i t}^{d} \ldots \ldots \ldots \ldots \ldots \ldots \ldots \ldots
\end{array}
$$

図 1 の処理フローでは，まず，起動停止変数を緩和した 条件のものと, 二次計画法を使って (1) 式の目的関数を最小 化する発電機出力, 起動停止変数の初期解を計算する。次 に，この初期解での各発電機の各時刻の発電単価を計算す る。この発電単価と繰り返し回数をもとにペナルティを加 算した (27) 式を目的関数として最小化問題を解く。これを 設定回数繰り返した後, 全ての火力の起動停止变数を 0 ま たは 1 に確定させて起動停止計画を作成する。最後に, 確 定し起動停止变数を固定にして，(1) 式を目的関数として, 二次計画法を使って負荷配分問題を解くことにより最適な 発電機出力を計算することができる。

以上により, 火力発電機の起動停止計画, 負荷配分計画, 揚水, 水力および融通電力を決定でき, 翌日の運用計画を 作成することができる。

\section{4. シミュレーション}

〈4・1〉対象モデル ここでは 1 時間毎の翌日 24 時 点の計画を作成する。図 2 に固定供給力分を除いた差引需 要を示す。最小需要は 5 時, 最大需要は 17 時に発生して いる。表 1 に計画作成条件，表 2 に最大供給力を示す。火 力発電機が 29 機で，そのうち 8 機が然料消費制約のある LNG 機としている。水力は 4 つのダムからなる連接水系 （図 3 参照。流下遅れ時間は全て 30 分）, 揚水発電所は 2 箇所（図 4 参照）としている。融通電力の銘柄は 1 つで, 3 つのパターン（24 時間一定，昼間一定，供給しない）があ る。全ての発電機の最小連続停止／運転時間は，それぞれ 3 時間， 5 時間に設定している。困 5 に各エリアに接続す る供給力を示す。

図 1 の処理フローで収束させるための繰り返し回数は 4 回としている。

$\langle\mathbf{4} \cdot \mathbf{2}\rangle$ 火力発電機のみのでの最適化結果 優先順位 法を用いた従来方法と提案手法の発電コストを比較するた

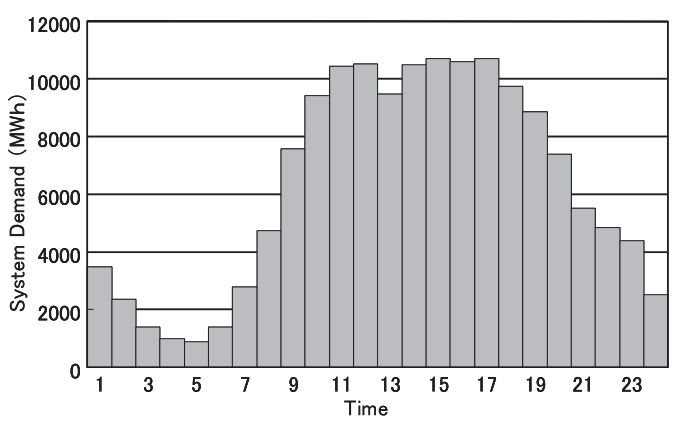

図 2 需要

Fig. 2. System demand.

表 1 計画作成条件

Table 1. Conditions of scheduling problem.

\begin{tabular}{|c|c|}
\hline Horizon in hours & 24 \\
\hline Operating reserve & $10 \%$ \\
\hline Thermal units (LNG units) & $29(8)$ \\
\hline Pumped-storage units & 2 \\
\hline Cascade-hydro units & 4 \\
\hline Minimum down-times & 3 \\
\hline Minimum up-times & 5 \\
\hline Interconnection power patterns & 3 \\
\hline
\end{tabular}

表 2 最大供給力

Table 2. Maximum supply (MW).

\begin{tabular}{|c|c|}
\hline Thermal & 12529 \\
\hline Pumped-storage hydro & 2000 \\
\hline Cascade hydro & 1100 \\
\hline Interconnection & 50 \\
\hline
\end{tabular}

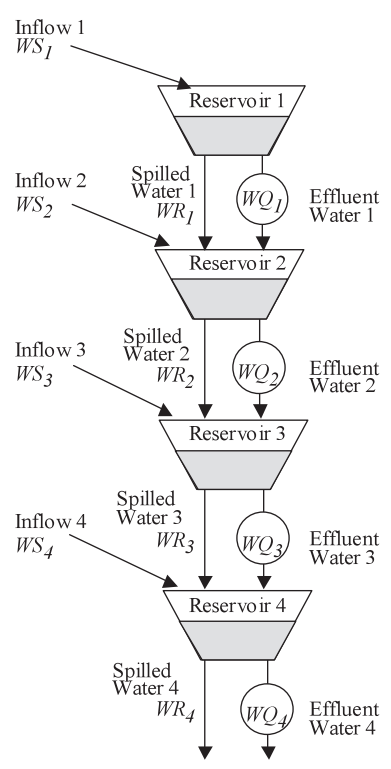

図 3 連接水系モデル

Fig. 3. Model of 4 cascade hydro units.

めに火力発電機のみを対象とした計画を作成する。また， 連系線潮流制約も考慮しないものとする。優先順位法では, 火力の定格出力での発電単価が安い順に予備力を満たすま で起動する発電機を決定することにより起動停止計画を作 成した。提案手法の最終計画および優先順位法の計画とも に(2)〜(6) 式までの制約条件を満たしている。 


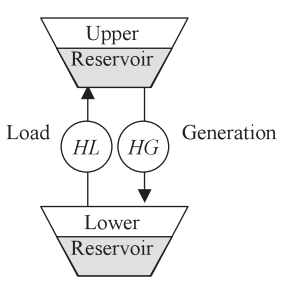

図 4 揚水モデル

Fig. 4. Model of pumped storage units.

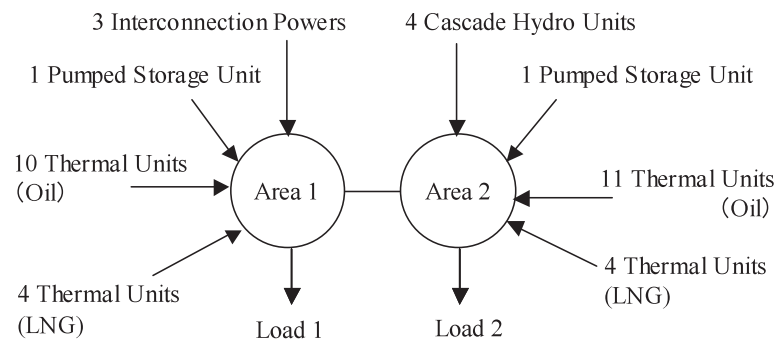

図 5 対象系統

Fig. 5. Test system.

表 3 火力の起動停止計画

Table 3. Thermal unit commitment.

Initial: Initial UC for proposed method, Final: Final UC for proposed method, PL: Priority List method, Capacity (MW), Priority: Priority orde

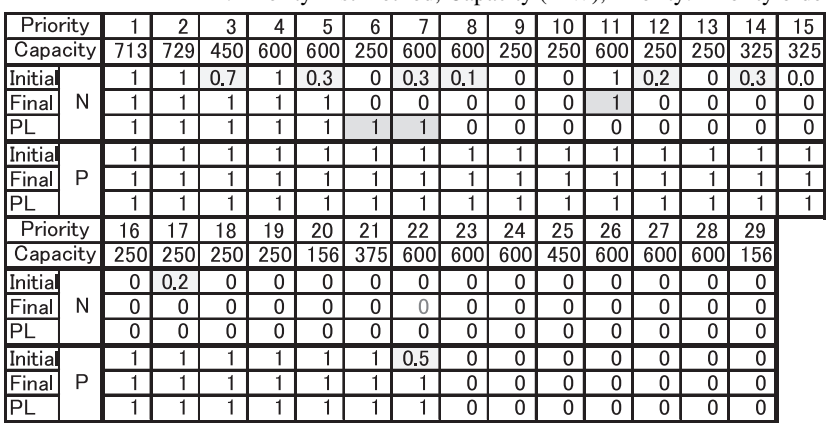

提案手法の初期計画では, 起動停止変数 0.1 以下が $40 \%$, 0.9 以上が $41 \%$ あった。収束計算により，起動停止変数 が 0 または 1 に収束しない未確定のものは，ほぼ各時刻で 1 つの発電機となった。これは，潮流制約などの制約を考 慮していないために，相対的に安い発電機は運転，高い発 電機は停止となり，必要最小限の予備力を確保し，発電コ ストを最小化するために， 1 台の発電機が 0 と 1 の実数に なったためである。この不確定な発電機を運転にすること により, 起動停止計画を確定し, 二次計画法で発電機出力 を計算した。

表 3 に時刻 $\mathrm{N}, \mathrm{P}$ の提案手法の初期計画，最終計画およ び優先順位法で作成した計画の起動停止を示す。時刻 P の 起動停止は提案手法の最終計画と優先順位法は一致してい ている。提案手法の初期計画も最終計画で運転している発 電機のなかで優先順位が最も低い優先順位 22 の発電機が

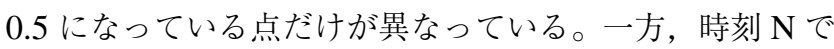
は, 最終計画では優先順位 11 の発電機が起動しているのに
表 4 発電費用の比較

Table 4. Generation and reduced costs. (Normalized by generation costs of conventional method)

\begin{tabular}{|c|c|c|c|}
\hline & $\begin{array}{c}\text { Conventional } \\
\text { Method }\end{array}$ & $\begin{array}{c}\text { Proposed } \\
\text { Method }\end{array}$ & $\begin{array}{c}\text { Lower Bound } \\
\text { (Initial schedule) }\end{array}$ \\
\hline $\begin{array}{c}\text { Generation } \\
\text { costs }\end{array}$ & $\begin{array}{c}1.00000 \\
(0.00000)\end{array}$ & $\begin{array}{c}0.99916 \\
(-0.00084)\end{array}$ & $\begin{array}{c}0.99335 \\
(-0.00665)\end{array}$ \\
\hline Fuel costs & 0.98974 & 0.98933 & 0.98430 \\
\hline Start-up costs & 0.01026 & 0.00982 & 0.00905 \\
\hline
\end{tabular}

対して, 優先順位法では優先順位 6 のみでは予備力が不足 するため優先順位 7 の発電機を起動させている点が異なっ ている。すなわち, 優先順位法より最終計画の方が予備力 を $250 \mathrm{MW}$ 小さくできていることがわかる。時刻 N, P 以 外の時刻でも予備力を少なくさせる傾向にあることを確認 している。時刻 N の初期計画と最終計画を比較すると初期 計画で起動停止変数が大きいほど, 最終計画で運転になる 傾向があることが分かる。

提案手法の最終計画と優先順位法の発電コストの比較を 表 4 に示す。提案手法の方が予備力を削減できている傾向 があるため燃料費を削減でき, 更に起動費も削減でき, 発 電コストを $0.084 \%$ 削減できている。提案手法では起動台 数 16 台と優先順位法より 1 台多いにもかかわらず, 起動 費を低減できている。この理由として，優先順位法では発 電単価が安いものから起動しているため, 起動費を考慮で きていない。一方，提案手法では燃料費と起動費を同時に 考慮して発電コストを最小化するように, 総合的に判断し て起動する発電機を決定している効果が出ていると考える。 また，発電コスト下限值に対する差異は，従来手法および 提案手法でそれぞれ $0.665 \%, 0.581 \%$ となっている。

〈4・3〉潮流制約を考慮した全供給力最適化結果提 案手法を用いて連系線潮流を考慮して火力, 揚水, 水力お よび融通電力の全供給力の最適化を図る。前節で潮流制約 を考慮しないときの火力発電機のみの計画を作成して, 従 来手法より発電コストを削減できることを示したので，こ こでは潮流制約を考慮した計画が作成できるかどうかを検 討する。

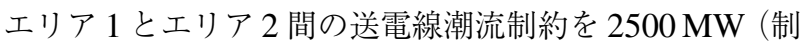
約無しに相当）からゼロとなるまで， $500 \mathrm{MW}$ ずつ減少さ せたときの翌日 24 時点の運用計画を作成した。いずれの 場合も〈2・2〉節で示した全ての制約条件を満たす最終計画 を作成することができた。

図 6〜図 8 は潮流制約無しのときの各供給力の出力であ る。融通電力については昼間だけ一定量を調達するパター ンが選ばれている。揚水の初期水位と最終水位は同一とし ている。深夜に揚水ポンプして, 昼間に発電している。深 夜と昼間の増分燃料費の比率は揚水効率と一致しており, 深夜および昼間の火力の供給力は一定となっていることか ら最適に負荷配分されていることが分かる。水力について はダム貯水上下限の範囲を十分大きく設定しているので, 燃料費の抑制効果が大きい需要の大きい時刻のみ発電して いる。13 時の揚水発電および 22 時の水力発電は経済性で 


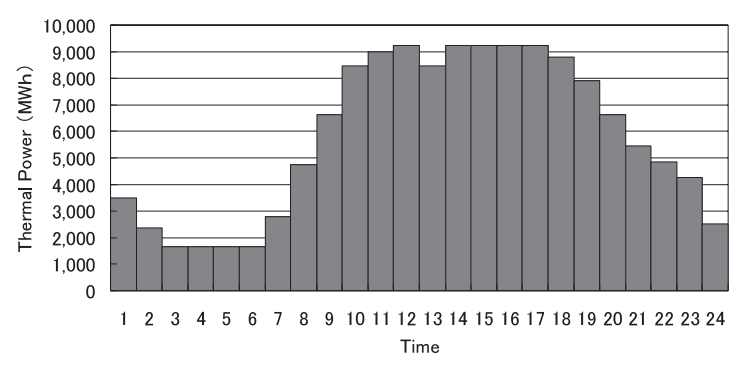

図 6 火力による供給力

Fig. 6. Total supply of thermal units.

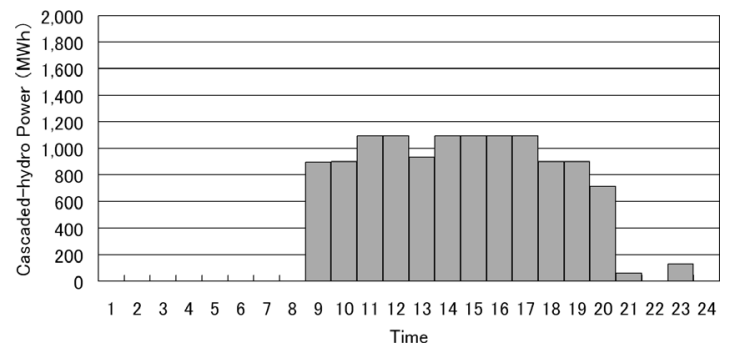

図 7 水力による供給力

Fig. 7. Total supply of cascaded hydro units.

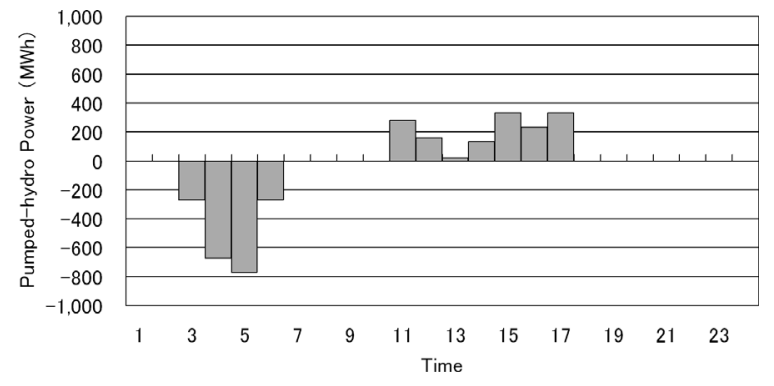

図 8 揚水による負荷と供給力

Fig. 8. Total supply of pumped-storage hydro units.

はなく，火力で保有する予備力制約を満足させるために利 用されており, この時刻の予備力は最小限の必要予備力と 一致している。以上のように, 揚水, 水力が効率的に利用 されていることが確認できた。

次に潮流制約により潮流值および発電コストの変化を検 討する。図 9 は潮流制約を変化させたときの各時刻の潮流 值を示している。潮流制約值が $2500 \mathrm{MW}$ の場合, 潮流方 向はエリア 1 からエリア 2 の向きで, 24 時点の間で 750 $2236 \mathrm{MW}$ の範囲となっている。潮流制約が $2500 \mathrm{MW}$ から $0 \mathrm{MW}$ に制限されるにつれて，潮流值が制約值と一致する 時刻が扔㧍くなるが，潮流制約を満足する計画を作成でき ていることを確認している。また，図 10 は潮流制約值を 変化させたときに発電コストの変化を示す。但し，発電コ ストは潮流制約無しのときを 1 として規格化している。図 中の記号けは起動停止変数を緩和したときの発電コストで, 起動停止変数が 0,1 に収束していないので運用可能解で はないが，発電コストの下限值を与える。記号山は全制約 を満たす最終計画の発電コストである。両者のコスト差上

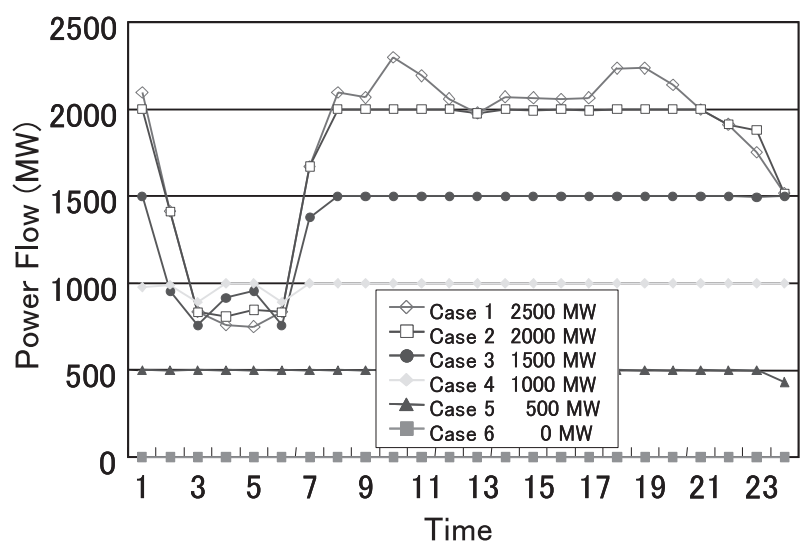

図 9 潮流制約の変化に対する潮流

Fig. 9. Power flow for all cases.

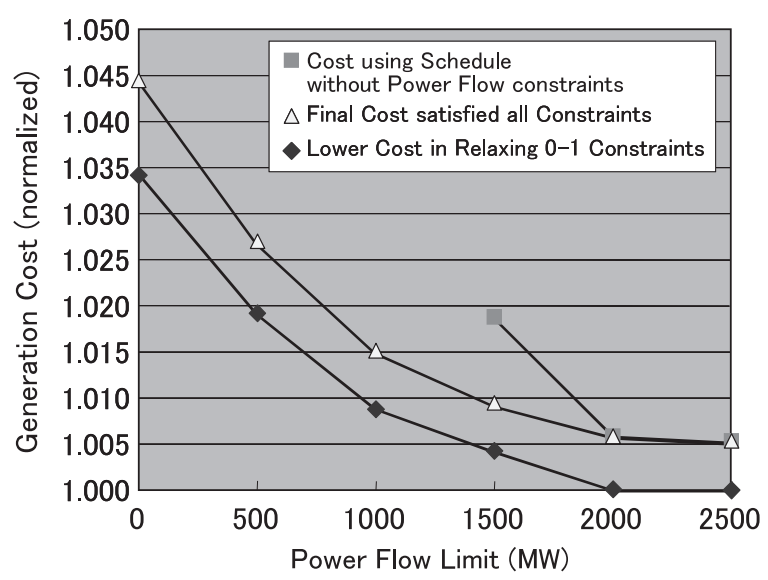

図 10 発電コストの比較

Fig. 10. Comparison of generation costs.

限值は，潮流制約值が厳しくなるにつれて $0.5 \sim 1.0 \% に$ 拡 大寸る傾向にあることが分かる。記号ロは潮流制約無しで 作成した起動停止計画を固定にして, 発電機出力を調整し たときの発電コストである。潮流制約值が $1000 \mathrm{MW}$ 以下 の時には制約条件を満たす計画を作成できず，競争環境下 などの影響で潮流制約が厳しくなったときには, 最初から 潮流制約を考慮した計画を作成することが必要になること が分かる。

\section{5. おわりに}

二次計画法を用いて, 火力発電機の起動停止計画および 火力, 揚水, 水力, 融通電力による供給力を同時に計画す る手法を開発した。火力発電機の起動停止変数を実数に緩 和するとともに，この変数に時間変化制約を加えることで 時間的に連続した計画を作成できるようにした。また，起 動停止をできるだけ， $0 ， 1$ に確定させるために，目的関数 に起動停止変数と発電単価の項を掛けたペナルティを導入 した。この開発した手法を実規模問題に適用して, 潮流制 約, 発電機の運用制約等を満たす翌日運用計画を作成する ことができた。今後は，更に実系統に近づけるべく，潮流 制約を考慮する送電線の数を増加させた条件のもとで，提 
案手法の有効性を確認していく予定である。

(平成 20 年 1 月 7 日受付，平成 20 年 4 月 2 日再受付）

\section{文献}

（1）経済産業省：「電気事業分科会会議」, http://www.enecho.meti.go.jp/ denkihp/bunkakai/

(2) N.P. Padhy: "Unit Commitment—Bibliographical Survey", IEEE Trans. Power Syst., Vol.19, No.2, pp.1196-1205 (2004-5)

(3) R.M. Burns and C.A. Gibson: "Optimization of priority lists for a unit commitment program", Proc. IEEE Power Eng. Soc. Summer Meeting (1975)

(4) F.N. Lee: "Short-term unit commitment a new method", IEEE Trans. Power Syst., Vol.3, pp.421-428 (1988-5)

(5) R.H. Liang and F.C. Kang: "Thermal generating unit commitment using an extended mean field annealing neural network", Proc. Inst. Elect. Eng., Gen. Transm. Dist., Vol.147, pp.164-170 (2000-5)

(6) F.N. Lee and Q. Feng: "Multi-area unit commitment", IEEE Trans. Power Syst., Vol.7, pp.591-599 (1992-5)

(7) M. Yoshikawa, T. Sawa, H. Nakashima, M. Kinoshita, Y. Kurebayashi, and Y. Nakata: "Method for Unit Commitment of Thermal and Pumpedstorage Hydro Power Plants", T. IEE Japan, Vol.114-B, No.12, pp.12201126 (1994-12) (in Japanese)

吉川元庸・澤 敏之·中島 宏・木下光夫・榑林芳之 - 中田祐司 :「火 力·揚水発電所の運用計画作成手法」, 電学論 B, 114, 12, pp.1220-1126 (1994-12)

(8) R. Nieva, A. Inda, and J. Frausto: "CHT: a digital computer package for solving short term hydro-thermal coordination and unit commitment problems", IEEE Trans. Power App. Syst., Vol.PAS-1, pp.168-174 (1986-8)

(9) W.L. Snyder, Jr., H.D. Powell, Jr., and J.C. Rayburn: "Dynamic programming approach to unit commitment", IEEE Trans. Power Syst., Vol.2, pp.339-347 (1987-5)

(10) C.K. Pang, G.B. Sheble, and F. Albu: "Evaluation of dynamic programming based methods and multiple area representation for thermal unit commitments", IEEE Trans. Power App. Syst., Vol.PAS-100, pp.1212-1218 (19813)

(11) G.S. Lauer, N.R. Sandell, Jr., N.R. Bertsekas, and T.A. Posbergh: "Solution of large scale optimal unit commitment problems", IEEE Trans. Power App. Syst., Vol.PAS-101, pp.79-96 (1982-1)

(12) A.I. Cohen and M. Yoshimura: "A branch- and -bound algorithm for unit commitment", IEEE Trans. Power App. Syst., Vol.PAS-102, pp.444-451 (1983-2)

(13) K.-Y. Huang, H.-T. Yang, and C.-L. Huang: "A new thermal unit commitment approach using constraint logic programming", IEEE Trans. Power Syst., Vol.13, pp.936-945 (1998-8)

(14) A. Merlin and P. Sandrin: "A new method for unit commitment at Electricite De France", IEEE Trans. Power App. Syst., Vol.PAS-102, pp.1218-1225 (1983-8)

(15) K. Aoki, M. Itoh, T. Satoh, K. Nara, and M. Kanezashi: "Optimal long-term unit commitment in large scale systems including fuel constrained thermal and pumped-storage hydro", IEEE Trans. Power Syst., Vol.4, pp.1065-1073 (1989-8)

(16) F. Zhuang and F.D. Galiana: "Toward a more rigorous and practical unit commitment by Lagrangian Relaxation", IEEE Trans. Power Syst., Vol.3, pp.763-773 (1988-5)

(17) D. Murata and S. Yamashiro: "Unit Commitment Scheduling by Lagrange Relaxation Method Taking into Account Transmission Losses", IEEJ Trans. $P E$, Vol.124, No.4, pp.546-552 (2004-4) (in Japanese)

村田大介・山城 迪：「送電損失を考慮したラグランジュ緩和法によ る火力発電機の起動停止計画」, 電学論 B, 124, 4, pp.546-552 (2004-4)

(18) T. Mitani, K. Nara, Y. Satoh, and H. Honma: "A Solution Method for Security Constrained Unit Commitment by Lagrangian Decomposition", IEEJ Trans. PE, Vol.127, No.10, pp.1080-1086 (2007-10) (in Japanese) 三谷 崇・奈良宏一・佐藤佳彦・本間 仁:「ラグランジュ分解によ るセキュリテイ制約付き発電機起動停止計画問題の解法」,電学論 B, 127, 10, pp.1080-1086 (2007-10)

(19) T. Nagata, H. Sasaki, H. Duo, H. Fujita, and T. Takayama: "Solution for Unit Commitment Problem Considering LNG Fuel Constraints", T. IEE Japan, Vol.116-B, No.12, pp.1517-1523 (1996-12) (in Japanese)

永田 武·佐々木博司 ·多 漢政・藤田秀紀・高山俊昭：「LNG 燃 料消費制約を考慮した発電機起動停止計画問題の解法」, 電学論 B, 116, 12, pp.1517-1523 (1996-12)

(20) C. Li, R.B. Johnson, and A.J. Svaboda: "A new unit commitment method", IEEE Trans. Power Syst., Vol.12, pp.113-119 (1997-2)
(21) R. Tanabe, A. Kurita, Y. Tada, H. Okamoto, and Y. Sekine: "A Practical Algorithm for Unit Commitment Based on Unit Decommitment Ranking", $T$. IEE Japan, Vol.120-B, No.12, pp.1595-1606 (2000-12) (in Japanese) 田辺隆也·栗田 篤・多田泰之・岡本 浩・関根泰次:「系統評価の ための停止ランキングに基づく電源起動停止計画手法」, 電学論 B, 120, 12, pp.1595-1606 (2000-12)

(22) T.T. Maifeld and G.B. Sheble: "Genetic-based unit commitment algorithm", IEEE Trans. Power Syst., Vol.11, pp.1359-1370 (1996-8)

(23) A. Rudolf and R. Bayrleithner: "A genetic algorithm for solving the unit commitment problem of a hydro-thermal power systems", IEEE Trans. Power Syst., Vol.14, pp.1460-1468 (1999-11)

(24) K.S. Swarup and S. Yamashiro: "Unit commitment solution methodology using genetic algorithm", IEEE Trans. Power Syst., Vol.17, pp.87-91 (20022)

(25) H. Mori and O. Matsuzaki: "Embedding the priority into Tabu search for unit commitment", Proc. IEEE Winter Meeting (2000)

(26) A.H. Mantawy, Y.L. Abdel-Magid, and S.Z. Selim: "Unit commitment by tabu search", Proc. Inst. Elect. Eng., Gen. Transm. Dist., Vol.145, No.1, pp.56-64 (1998-1)

(27) J.J. Shaw: "A Direct Method for Security-Constrained Unit commitment", IEEE Trans. Power Syst., Vol.10, No.3, pp.1329-1342 (1995-8)

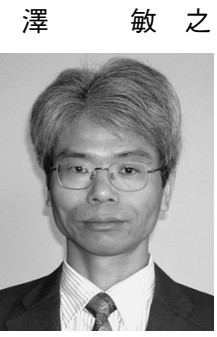

（上級会員） 1959 年 1 月 28 日生。1984 年 3 月 東京大学大学院工学系研究科修士課程修了。同年 4 月，(株）日立製作所に入社。現在，同社日立 研究所に勤務。主に, 電力系統の需要予測, 運用 計画，電力自由化関連システム等の研究に従事。 茨城大学工学部非常勤講師 (2004 年より)。IEEE 会員。

佐 藤 康 生 (正員) 1969 年 9 月 22 日生。1994 年 3 月横浜

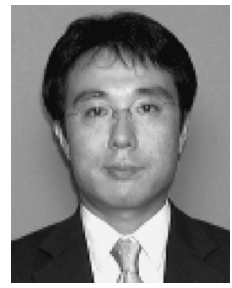
国立大学大学院工学研究科修士課程修了。同年 4 月，(株）日立製作所に入社。現在，同社日立研 究所に勤務。主として, 電力自由化に拐ける電力 系統の計画・運用の高度化や電力取引支援等の研 究に従事。

鶴 貝 満 男 (正員) 1968 年 3 月 17 日生。1993 年 3 月東北

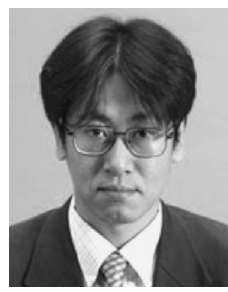
大学理学系研究科修士課程修了。同年 4 月，(株) 日立製作所に入社。現在，同社情報制御システム 事業部電力システム設計部に勤務。主に, 電力系 統の需給制御, 電力自由化関連システム等の研究 に従事。

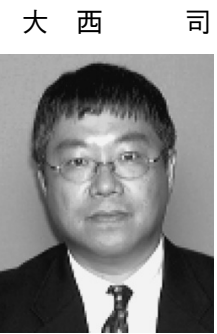

(正員) 1963 年 6 月 13 日生。 1992 年 3 月大阪 大学基礎工学部制御工学科卒業。同年 4 月, (株) 日立製作所に入社。現在，同社情報制御システム 事業部電力システム設計部に勤務。主に, 電力系 統の監視制御システム等の設計／開発に従事。 